\title{
Priprioca (Cyperus articulatus var. nodosus, Cyperaceae) Hydrolate as Larvicidal against Aedes aegypti
}

\author{
Inês Ribeiro Machado ${ }^{1}$, Keila Rêgo Mendes ${ }^{2}$, Adriano Rodrigues de Paula ${ }^{3}$, Michelly Rios Arévalo \\ Amanda Sousa Silva 4 \& Lauro Euclides Soares Barata ${ }^{4}$
}

Recebido em 30/04/2020 - Aceito em 31/08/2020

1 Universidade Estadual do Norte Fluminense Darcy Ribeiro. <ines_uenf_22@hotmail.com>.

2 Instituto Chico Mendes de Conservação da Biodiversidade/ICMBio, EQSW 103/104, Bloco "B", Complexo Administrativo, Setor Sudoeste, Brasília/DF, Brasil. CEP: 70.670-350. <kbio18@yahoo.com.br>.

3 Laboratório de Entomologia e Fitopatologia, Universidade Estadual do Norte Fluminense Darcy Ribeiro/UENF. <biodepaula@yahoo.com.br>.

4 Laboratório P\&D de Produtos Naturais Bioativos, Instituto de Biodiversidade e Florestas/IBEF, Universidade Federal do Oeste do Pará/UFOPA. <michrios76@yahoo.com.br, amanda_silvasousa@hotmail.com, lauroessbarata@gmail.com>.

\begin{abstract}
Dengue cases have grown significantly in Brazil in recent years. Studies with plant extracts show the insecticidal potential of bioactive substances that become candidates for future commercial products. This work evaluated the larvicidal effect of essential oil, without hydrolysis of Cyperus articulatus var. nodosus against the third and fourth wide stage of Aedes aegypti, which reduces larvae survival by as much as the $3^{\text {th }}$ and $4^{\text {th }}$ instar of Ae. aegypti. A chemical characterization of the hydrogen skeletons was performed by the GC-MS, revealing verbenone (\%), trans-sabinol (\%) and mirtenol (\%) as major compounds.
\end{abstract}

Keywords: Dengue; Aedes aegypti; priprioca; Cyperus articulatus var. nodosus, larvicidal activity.

\section{Hidrolato de Priprioca (Cyperus articulatus var. nodosus, Cyperaceae) como Agente Larvicida contra Aedes aegypti}

RESUMO - Os casos de dengue apresentam importante crescimento no Brasil nos últimos anos. Estudos com extratos de plantas mostram o potencial inseticida de substâncias bioativas que as torna candidatas a futuros produtos comerciais. Este trabalho avaliou o efeito larvicida do óleo essencial contido no hidrolato dos rizomas de Cyperus articulatus var. nodosus contra o terceiro e quarto estágio de larvas de Aedes aegypti, reduzindo a sobrevivência de larvas tanto do terceiro quanto do quarto instar do Ae. aegypti. A caracterização química dos sesquiterpenos do hidrolato foi realizada por GC-MS, revelando como compostos majoritários a verbenona (\%), o trans-sabinol (\%) e o mirtenol (\%).

Palavras-chave: Dengue; priprioca; Cyperus articulatus var. nodosus; atividade larvicida.

\section{Hidrolato de Priprioca (Cyperus articulatus var. nodosus, Cyperaceae) como Agente Larvicida contra Aedes aegypti}

RESUMEN - Los casos de dengue han crecido significativamente en Brasil en los últimos años. Los estudios con extractos de plantas muestran el potencial insecticida de sustancias bioactivas que las hace candidatas para futuros productos comerciales. Este trabajo evaluó el efecto larvicida del aceite esencial contenido en el hidrolato de los rizomas de Cyperus articulatus var. nodosus contra larvas del tercer y cuarto estadio de Aedes aegypti, lo que reduce la supervivencia larvaria del tercer y cuarto estadio de Ae. aegypti. La caracterización química de los sesquiterpenos hidrolatos se realizó mediante GC-MS, revelando verbenona (\%), trans-sabinol (\%) y mirtenol (\%) como compuestos principales.

Palabras clave: Dengue; Priprioca; Cyperus articulatus var. nodosus; actividad larvicida. 


\section{Introduction}

Aedes aegypti (Diptera: Culicidae) is a cosmopolitan mosquito occurring in tropical and subtropical regions around the world. It is essentially anthropophylic found in urban areas and rural villages (Edman et al. 1992, OMS 2011, Tauil 2002, Silva et al. 2004). This mosquito has medical importance because it is the dengue and yellow fever vector. Actually, the reappearance of dengue in the last decades transformed this disease in a serious public health issue, mainly in tropical countries (Instituto Virtual da Dengue 2012).

Dengue can infect more than 390 million persons per year (WHO 2014). World Health Organization point out Brazil as one of the most endemical countries with more registrations of the disease. Dengue is arising due not planned urbanization, lack of sanitation, ineffective control of mosquitos, demographic growth and long distance trips. Furthermore, there is no vaccine against the disease. Estimation of $40 \%$ of the population is at risk worldwide. Dengue in severe form affects mainly Asian and Latin American countries, being one of the main causes of hospitalization and child mortality in these regions.

There are many cases of resistance related to the mosquito-vector in the world and particularly for the population of Ae. aegypti in Brazil. There are reports of occurrence of resistance to organophosphorated insecticides, at least in eigth cities of São Paulo State with detection of resistance against larvicide temephós (Abate ${ }^{\circledR}$ ) (Andrade \& Modolo 1991, Macoris et al. 1999).

Control of the vector Ae. aegypti includes vigilance, reduction of the source (or environmental management), biological control, chemical control by using insecticides and repellents, traps and management of the resistance to insecticides. Chemical control with insecticides of organic or inorganic origin is one of the methodologies adopted as part of integrated management for the control of vectors in Public Health (Rose 2011).

Brazil has a great diversity of plants, more than 56 thousand species, around $19 \%$ of the total flora of the world (Giulietti et al. 2005). Investigations with vegetal species show the potential to find insecticidal molecules, some of them highly selective, that could be used in the development of new formulations.
Species of Cyperaceae present great importance in Amazonian pharmacopoeia, being used mainly as contraceptive, analgesic and in the treatment of diarrhea. In Pará State, priprioca have aroused growing scientific and economical interest due to the pleasant aroma of essential oil obtained from the rhizomes that are very used to prepare perfumes. Essential oils from these species have mainly sesquiterpenes belonging to the class of cyperene, caryophyllane, eudesmane, patchoulane and rontundane (Zoghbi et al. 2006). Volatile terpenes and phenylpropanoids can have, depending of the insect, attractive properties (feeding, polinization) and/or deterrent and insecticide (Kainulainen et al. 1998). Larvicide activity of terpenoids were reported on literature.

Hydrolates are aqueous solutions obtained as subproducts from hydrodistillation or steam distillation process of essential oils. These subproducts are normally discarded at the end of the process. The main compounds of hydrolates are the more hydrophilic molecules presented in essential oils. Many studies showed activity of plant extracts against different species of mosquitos (Guimarães et al. 2001), including Ae. aegypti (Silva et al. 2004).

The present study had as aim to evaluate the larvicidal effect of hydrolate obtained from priprioca (Cyperus articulatus var. nodosus) rhizomes against third and fourth stages of $A e$. aegypti larvae.

\section{Material and Methods}

\section{Hydrolate preparation of priprioca (C. articulatus var. nodosus)}

Priprioca roots $(4 \mathrm{~kg})$ were collected at Tabocal 1 district, 23km far away of Santarém, Pará, Brazil, between 8 and 10am. Tubers were washed and dried in the oven at $40^{\circ} \mathrm{C}$ during $24 \mathrm{~h}$ until constant weight. After grinding in a grinder Trapp 200, the powder was extracted with distilled water in a steam hydrodistillator of 150L. Essential oil was separated and remanescent hydrolate was collected.

\section{Aedes aegypti larvae (Rockfeller strain)}

Adult mosquitos of Ae. aegypti were procreated in plastic recipients covered with cloth 
and maintained at $25^{\circ} \mathrm{C}, 75 \%$ relative humidity, $12 \mathrm{~h}$ photoperiod. An immobilized mouse in a wire mesh was exposed to the mosquitos for blood feeding. Oviposition of female Ae. aegypti occurred in filter paper that covered a plastic vase $(100 \mathrm{~mL})$ filled with $50 \mathrm{~mL}$ of tap water. Larvae hatching was stimulated by total immersion of filter paper containing the eggs in a recipient with $100 \mathrm{~mL}$ water, which was treated $24 \mathrm{~h}$ prior with mice feed. Larvae of $3^{\text {th }}$ or $4^{\text {th }}$ stages were selected to be use in the experiments. A group of larvae was maintained to continue the reproduction of mosquitos. These larvae were treated daily with mice feed until the formation of pupas, when they were transferred to plastic vases and kept in a plastic recipient. Adult mosquitos were fed with saccharose solution $(10 \%)$ and then the reproductive cycle was restarted.

Plastic vases of $100 \mathrm{~mL}$ were used in the experiments. Each vase was filled with tap water and the hydrolate (totalizing $50 \mathrm{~mL}$ of formulation), followed by addition of $10 \mathrm{Ae}$. aegypti larvae. Larvae were daily fed with $0.05 \%$ of cat feed. Hydrolate was evaluated in three different concentrations, diluting the hydrolate in water: 1:1, 1:0.5 and 1:0.125. A control was prepared just containing tap water. The experiment was conducted in triplicates.

Larval survival was checked daily $24 \mathrm{~h}$ after the beginning of the assay, during seven days. Larvae were considered alive when they showed movements or reaction to the contact with a Pasteur pipette. The assay was kept at $27-30^{\circ} \mathrm{C}$. Larval survival curves and average survival time (S50) of the larvae were calculated by GraphPad Prism 3.0 Software. Larval survival percentage were done using Excel 2010 Software.

\section{Extraction of hydrolate with methylene chloride}

A $50 \mathrm{~mL}$ of hydrolate was transferred to a separation funnel and $25 \mathrm{~mL}$ methylene chloride was added. After 3-fold extraction, organic phase was separated, dried with anhydrous $\mathrm{Na}_{2} \mathrm{SO}_{4}$ and evaporated under vacuum to dryness.

\section{GC-MS analysis}

Volatile constituents were analysed by GC Agilent, HP-6890, with a selective mass detector, Agilent HP-5975, using capilar column HP-5MS ( $30 \mathrm{~m} \times 0,25 \mathrm{~mm} \times 0,25 \mu \mathrm{m})$. The following conditions were adopted: injector temperature $=220^{\circ} \mathrm{C}$, column $=60^{\circ} \mathrm{C}$, heating rate from $3^{\circ} \mathrm{C} / \mathrm{min}$ to $240^{\circ} \mathrm{C} / \mathrm{min}$, and detecto $\mathrm{r}=250^{\circ} \mathrm{C}$. Helium was the carrier gas in an outflow of $1 \mathrm{~mL} / \mathrm{min}$. Selective mass detector operated at $70 \mathrm{eV}, \mathrm{m} / \mathrm{z}=30 \mathrm{a}$ 500amu.

Essential oil was dissolved in ethyl acetate in the concentration of $20 \mathrm{mg} / \mathrm{mL}$ and identification was carried out by retention index of the compounds, using a coinjection of a mixture of hydrocarbon standards ( $\mathrm{C} 8$ to $\mathrm{C} 22$ ), comparing with the electronic library of the GC system (NIST-11) and literature data (Adams 2007).

\section{Results}

Third stage larvae exposed to the highest concentration of hydrolate (1:1 dilution) showed the less survival rate $(36.6 \%)$ compared to the others treatments, after seven days evaluation (Table 1). The untreated control had $83.3 \%$ live larvae at the end point of the test. Dilution 1:1 of the hydrolate was the only one to present $S_{50}$ (3.5 days).

Table 1 - Surviving rate $(\%) \pm \mathrm{SE}$ and average time of surviving $\left(\mathrm{S}_{50}\right)$ of Ae. aegypti $3^{\text {th }}$ stage larvae exposed to hydrolate.

\begin{tabular}{|c|c|c|c|c|}
\hline Hydrolate dilutions & $\mathbf{1 : 1}$ & $\mathbf{1 : 0 . 5}$ & $\mathbf{1 : 0 . 2 5}$ & Control \\
\hline Surviving of the larvae (\%) & $36.6 \pm 2.36$ & $60.0 \pm 1.60$ & $80.0 \pm 0.69$ & $83.3 \pm 0.48$ \\
\hline $\mathrm{S}_{50}$ & 3.5 & $\mathrm{ND}$ & $\mathrm{ND}$ & ND \\
\hline
\end{tabular}

$\mathrm{ND}=$ not determined data. 


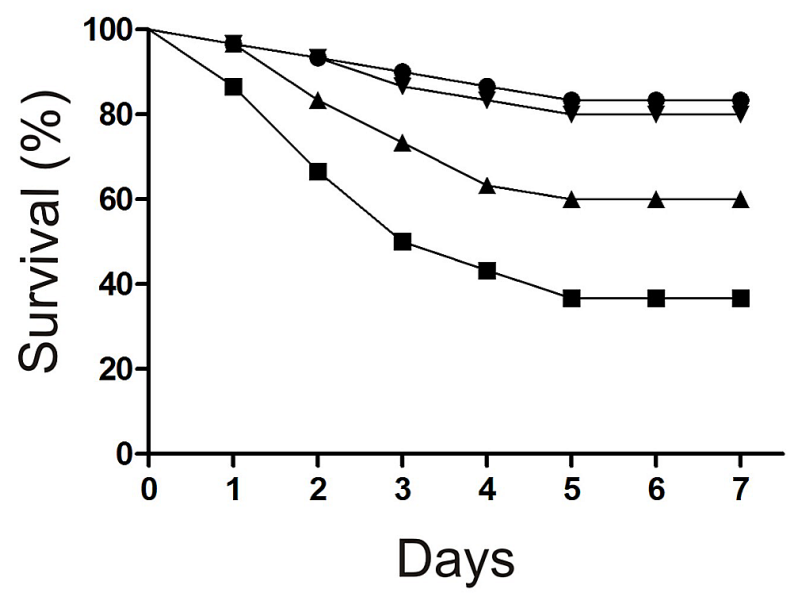

$\rightarrow 1: 1 \rightarrow 1: 0.25$
$\leftarrow 1: 0.5 \rightarrow$ control

Figure 1 - Daily survival curves of $3^{\text {th }}$ instar larvae exposed to three dilutions of the hydrolate. Untreated control was prepared with water only.

All fourth stage larvae died $(0 \%)$ when treated with $1: 1$ dilution of the hydrolate, compared to the other treatments, after seven days (Table 2). The untreated control showed $80 \%$ live larvae at the end of the experiment.
1:1 dilution caused less $S_{50}$ value (3 days), while 1:0.5 dilution caused $S_{50}$ value of four days to the larvae. Figure 2 shows daily survival curves of larvae exposed to three dilutions of the hydrolate. Treatment control was done with water only.

Table 2 - Surviving rate $(\%) \pm \mathrm{SE}$ and average time of surviving $\left(\mathrm{S}_{50}\right)$ of Ae. aegypti $4^{\text {th }}$ stage larvae exposed to hydrolate.

\begin{tabular}{|c|c|c|c|c|}
\hline Hydrolate dilutions & $\mathbf{1 : 1}$ & $\mathbf{1 : 0 . 5}$ & $\mathbf{1 : 0 . 2 5}$ & Control \\
\hline Surviving of larvae (\%) & $0.0 \pm 3.90$ & $26.6 \pm 3.43$ & $76.6 \pm 0.81$ & $80.0 \pm 0.69$ \\
\hline $\mathrm{S}_{50}$ & 3.0 & 4.0 & ND & ND \\
\hline
\end{tabular}

$\mathrm{ND}=$ not determined data.
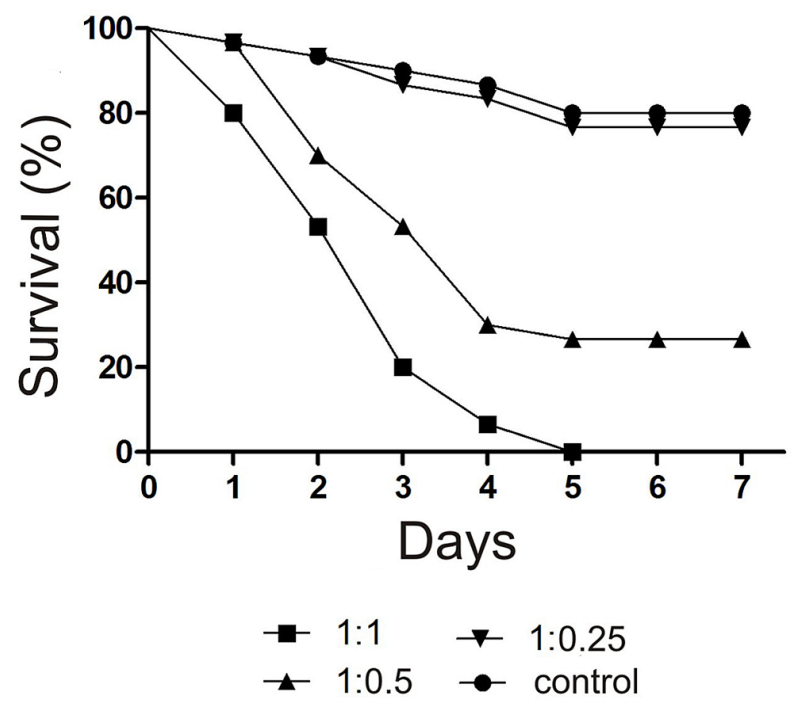

Figure 2 - Daily survival curves of $4^{\text {th }}$ instar larvae exposed to three dilutions of the hydrolate. Untreated control was prepared with water only. 
Chromatographic analysis by GC-MS (Figure 3) revealed that major compounds presented on hydrolate are verbenone $(31.7 \%)$, followed by trans-sabinol (13.9\%) and myrtenol (13.2\%) (Table 3).

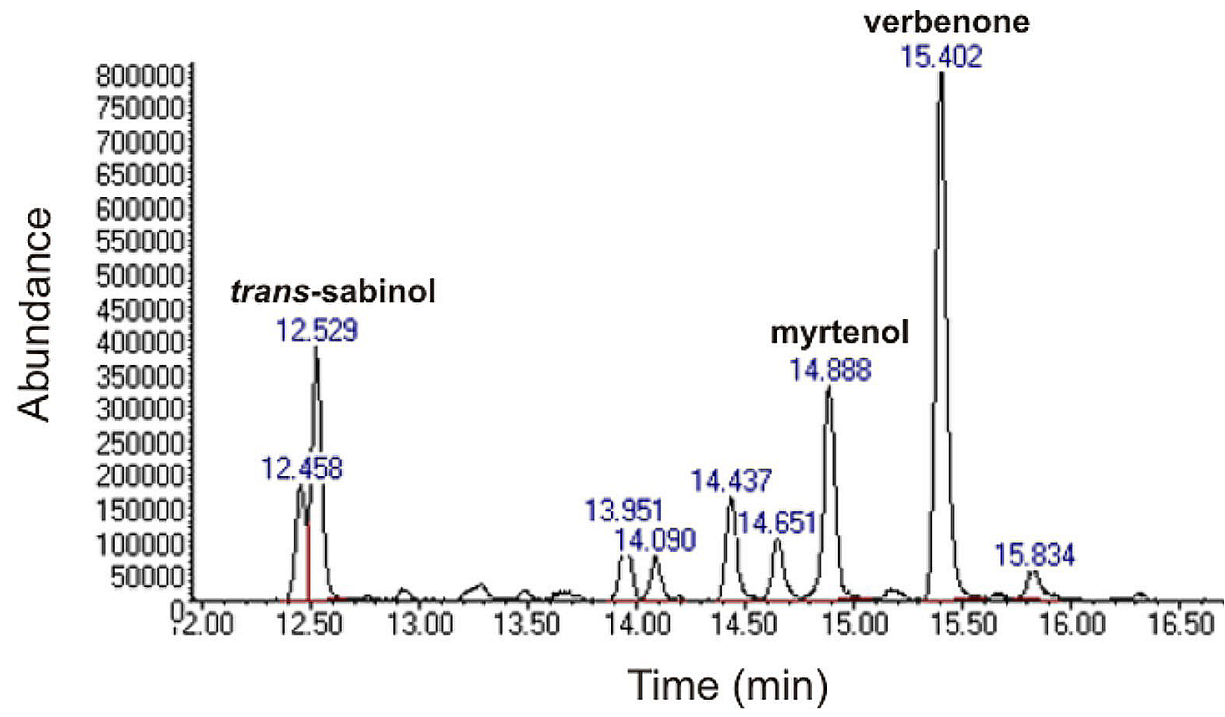

Figure 3 - Chromatographic analysis by GC-MS of $C$. articulatus var. nodosus hydrolate.

Table 3 - Volatile compounds identified by GC-MS in sample of the hydrolate from priprioca.

\begin{tabular}{|c|c|c|c|}
\hline $\mathbf{t}_{\mathbf{R}}(\mathbf{m i n})$ & $\mathbf{I R}$ & Compound & \% rel. \\
\hline 12,46 & 1137 & Nopinone & 5,69 \\
\hline 12,53 & 1139 & trans-sabinol & 13,89 \\
\hline 13,95 & 1174 & cis-pinocamphone & 4,05 \\
\hline 14,09 & 1177 & terpin-4-ol & 2,59 \\
\hline 14,44 & 1186 & M=150 & 6,02 \\
\hline 14,65 & 1191 & alfa-terpineol & 3,86 \\
\hline 14,89 & 1197 & Myrtenol & 13,20 \\
\hline 15,40 & 1209 & Verbenone & 31,74 \\
\hline 15,83 & 1220 & trans-carveol & 2,19 \\
\hline 34,13 & 1677 & Mustacone & 2,38 \\
\hline 34,28 & 1682 & $M=218$ & 1,80 \\
\hline 36,07 & 1732 & $M=236$ & 1,90 \\
\hline 40,21 & 1852 & $M=252$ & 1,30 \\
\hline 40,82 & 1871 & $M=238$ & 2,55 \\
\hline 41,27 & 1884 & $M=234$ & 3,73 \\
\hline 43,28 & 1946 & $M=236$ & 3,12 \\
\hline
\end{tabular}

$\mathrm{M}=$ molar mass of not identified compounds. 


\section{Discussion}

Terpenoids, especially limonoids, are compounds known for their insecticide potential. Although, simple monoterpenes also possess this potential, protecting plants from insect attacks (Vieira et al. 2011).

Regarding hydrolate of $C$. articulatus var. nodosus, $3^{\text {th }}$ stage larvae exposed to $1: 1$ dilution of the hydrolate presented in $7^{\text {th }}$ day of evaluation, the minor survival rate $(36.6 \%)$ compared to other treatments (Table 1 ). By another hand, $4^{\text {th }}$ stage larvae exposed to the same dilution, showed $0 \%$ of survival.

According to literature, the most active compounds of essential oil against Ae. aegypti are phenylpropanoids and sesquiterpenoids (Simas et al. 2004). Larvicide activity of terpenoids have been reported on literature, highlighting monoterpene $\beta$-thujaplicina (Jang et al. 2005) and sesquiterpenes 6-E-nerolidol, desidrocostos lactona and mansona C (Simas et al. 2004, Neves et al. 1999, Tiew et al. 2003). Monoterpene $\beta$-thujaplicina isolated from Chamaecyparis obtusa, also known as hinokitiol, has antimicrobial and phytoalexinic properties and larvicide activity against Ae. aegypti (Jang et al. 2005).

Larvicidal activity of essential oils from Brazilian Northeast plants showed good results, with $\mathrm{LC}_{50}=67 \mathrm{ppm}$ for Ocimum americanum and $\mathrm{LC}_{50}=60 \mathrm{ppm}$ for $O$. gratissimum. The main components of the essential oils were $E$-methyleugenol and cinnamate both derived from phenylpropanoids (Cavalcanti et al. 2004).

Carvalho et al. (2003) showed larvicidal activity against Ae. aegypti using the pure hydrolate of Lippia sidoides (known as pepper rosemary in Brazil) and its dilutions. Further, the major component of essential oil from leaves of this species - timol - was also evaluated. Hydrolate induced mortality almost instantaneously for all larvae, while timol caused $100 \%$ mortality with $0.017 \%$ concentration after $1.5 \mathrm{~h}$.

Larvicidal activity of essencial oil from two Cyperaceae species, Cyperus giganteus and $C$. rotundus against $A$. albopictus larvae was assayed (Kempraj \& Bhat 2008). The results showed that $C$. giganteus has highest biocidal effect compared to $C$. rotundus. One of the major compounds of essential oil from $C$. rotundus is $\alpha$-cyperone (Kilani et al. 2005, Tam et al. 2007) and it present insecticidal potential against clothes moth and beetles (Dadang et al. 1996, Adedire et al. 1999). Nevertheless, the presence of $\alpha$-cyperone has not been reported in tested essential oil of C. rotundus. Therefore it is presumable that other compounds could act as larvicidal in this essential oil.

Substances as verbenone are known to present insecticidal, antioxidant and antimicrobial properties (Angioni et al. 2004, Kabouche et al. 2005, Sacchetti et al. 2005, Santoyo et al. 2005, Prins et al. 2006, Celiktas et al. 2007, Gachkar et al. 2007). The hydrolate of Cyperus articulatus var. nodosus has verbenone as major compound (31.74\%), followed by trans-sabinol and myrtenol, $13.89 \%$ and $13.20 \%$, respectively. Although the insecticidal potential of verbenone is already described in literature, it is possible that these three major substances could be acting synergistically or separately causing mortality for $3^{\text {th }}$ and $4^{\text {th }}$ stage larvae of Ae. aegypti.

Furthermore, hydrolate of $C$. articulatus var. nodosus can presente more plar compounds as flavonoids and glycosides, although GC-MS analysis cannot detect such substances.

\section{Conclusion}

Third and fourth stage larvae exposed to 1:1 dilution of priprioca hydrolate presented minor survival rate compared to other treatments (1:0.5 and 1:0.025) and untreated control. The hydrolate decreased the survival of these larvae and for that reason it could be investigated as a control agent against this vector. More studies need to be done aiming to isolate insecticidal substances presented in $C$. articulatus var. nodosus hydrolate.

\section{Acknowledgements}

We are thankful to Universidade Estadual no Norte Fluminense (UENF), Prof. Richard Ian Samuels and Adriano Rodrigues de Paula for technical support and Coordenação de Aperfeiçoamento de Pessoal de Ensino Superior (CAPES) (grants to LESB, IMR and MRA) as well Coordenação Nacional de Desenvolvimento Científico e Tecnológico (CNPq) (grant to AS). 


\section{References}

Adams RP. 2007. "Identification of essential oil components by gas chromatography/mass spectroscopy", Allured Publishing. 807p.

Adedire $\mathrm{CO} \&$ Lajide L. Toxicity and oviposition ldeterrency of some plant extract on Cowpea storage bruchid, Callosobruchus maculus, Z. Pflanzekr Pflanzenschutz, 106: 647-653, 1999.

Andrade CFS \& Modolo M. Susceptibility of Aedes aegypti larvae to temephos and Bacillus thuringiensis var. israelensis in integrated control. Rev. Saúde públ. (S. Paulo), 25: 184-187, 1991.

Angioni A et al. Chemical composition, plant genetic differences, antimicrobial and antifungal activity investigation of the essential oil of Rosmarinus officinalis L. Journal of Agricultural and Food Chemistry, 52(11): 3530-3535, 2004.

Carvalho AFU, Melo VM, Craveiro AA, Machado MI, Bantim MB \& Rabelo EF. Larvicidal activity of the essential oil from Lippia sidoides Cham. against Aedes aegypti Linn. Mem Inst Oswaldo Cruz, 98(4): 569-571, 2003.

Cavalcanti ESB, Morais SM, Lima MAA \& Santana EWP. Larvicidal activity of essential oils from Brazilian plants against Aedes aegypti L. Mem. Inst. Oswaldo Cruz, 98: 541-544, 2004.

Celiktas OY et al. Antimicrobial activities of methanol extracts and essential oils of Rosmarinus officinalis, depending on location and seasonal variations. Food Chemistry, 1(100): 553-559, 2007.

Dadang KO, Kato S \& Yamamoto I. Insecticidal compound in tuber of Cyperus rotundus Linn. Against Diamondback Moth larvae. J. Pest Sci, 21: 444-446, 1996.

Edman JD, Strickman D, Kittayapong P, Scott TW \& Eiras AE. 2000. Culicidae. In: Neves, David Pereira (orgs.). Parasitologia humana. 10. ed. Atheneu. 428p.

Gachkar L et al. Chemical and biological characteristics of Cuminum cyminum and Rosmarinus officinalis essential oils. Food Chemistry, 102(3): 898-904, 2007.

Giulietti AM, Harley RM, Queiroz LP, Wanderley ML \& Berg CVD. Biodiversidade e conservação das plantas. no Brasil. Megadiversidade, 1: 52-61, 2005.

Guimarães VP, Silva IG, Silva HHG \& Rocha C. Atividade larvicida do extrato bruto etanólico da casca do caule de Magonia pubescens St. Hil. sobre Aedes albopictus (Skuse, 1894) (Diptera, Culicidae). Rev. Pat. trop., 30: 243-249, 2001.

Instituto Virtual da Dengue do Estado do Rio de Janeiro. Disponível em: <http://www.ivdrj.ufrj.br>. Acesso em: 03/08/2012.
JangYS, Jeon JH \& Lee HSJ. Am. Mosq. Control. Assoc, 21: 400, 2005.

Kabouche $\mathrm{Z}$ et al. Comparative antibacterial activity of five Lamiaceae essential oils from Algeria. International Journal Aromatherapy, 15(3): 129-133, 2005.

Kainulainen P, Tarhanen J, Tiilikkala K \& Holopainen JK. J. Agric. Food Chem., 46: 3780, 1998.

Kempraj V \& Bhat SK. Ovicidal and larvicidal activities of Cyperus giganteus Vahl and Cyperus rotundus Linn. Essential oils against Aedes albopictus (Skuse). Natural Product Radiance, 7: 416-419, 2008.

Kilani S, Abelwahed A, Ammar RB \& Hayder N. Chemical composition, antibacterial and antimutagenic activities of essencial oils from (Tunisian) Cyperus rotundus. J. Essent Oil Res, 17: 695-700, 2005.

Macoris MLG, Andrighetti MTM, Takaku L, Glasser CM, Garbeloto VC \& Cirino VCB. Alteração da resposta de susceptibilidade de Aedes aegypti a inseticidas organofosforados em municípios do Estado de São Paulo, Brasil. Rev. Saúde públ. (S. Paulo), 33: 521-522, 1999.

Neves M, Morais R, Gafner S, StoecklI EH \& Hostettmann K. Phytochemistry, 50: 967, 1999.

OMS - Organização Mundial da Saúde. Disponível em: <http://www.who.int/en/>. Acesso em: 11/06/ 2011.

Organização Mundial da Saúde - Dados da dengue no Brasil, 2014. Disponível em: <http://www.valor. com.br/brasil/3505186/oms-estima-que-dengue-podeinfectar-390-milhoes-por-ano-no-mundo $>$. Acesso em: $29 / 04 / 2014$.

Prins CL, Lemos CLS \& Freitas SP. Efeito do tempo de extração sobre a composição e o rendimento do óleo essencial de alecrim (Rosmarinus officinalis). Revista Brasileira de Plantas Medicinais, 8(4): 92-5, 2006.

Rose RI. Pesticides and public health: integrated methods of mosquito management. Emerg. Infec. Dis., 7(1): 17-23, 2001.

Sacchetti $G$ et al. Comparative evaluation of 11 essential oils of different origin as functional antioxidants, antiradicals and antimicrobials in foods. Food Chemistry, 91(4): 621-32, 2005.

Santoyo $\mathrm{S}$ et al. Chemical composition and antimicrobial activity of Rosmarinus officinalis L. essential oil obtained via supercritical fluid extraction. Journal of Food Protection, 68(4): 790-5, 2005.

SES, Secretaria de Estado de Saúde. Disponível em:<www.saude.rj.gov.br>. Acesso em: 16/04/2013.

Silva HHG, Da IG, Da Silva RMG, Dos Santos ER \& Filho CNE. Larvicidal activity of tannins isolated of Magonia pubescens St. Hil. (Sapindaceae) against 
Aedes aegypti (Diptera, Culicidae). Rev. Soc. Bras. Med. Trop., 37: 396-399, 2004.

Silva HHG, Silva IG, Santos RMG, Rodrigues Filho E \& Elias CN. Larvicidal activity of tannins isolated of Magonia pubescens St. Hil. (Sapindaceae) against Aedes aegypti (Diptera, Culicidae). Rev. Soc. Bras. Med. Trop., 37: 396-399, 2004.

Simas NK, Lima EC, Conceição SR, Kuster RM \& Oliveira Filho AM. Produtos naturais para o controle da transmissão da dengue: atividade larvicida de Myroxylon balsamum (óleo vermelho) e de terpenóides e fenilpropanóides. Quím. nova, 27: 46-49, 2004.

Tam CU, Yang FQ, Zhang QW, Guan J \& Li SP. Optimization and comparison of three methods for extraction of volatile compounds from Cyperus rotundus evaluated by gas chromatography-mass spectrometry. J. Pharm Biomed Anal, 44: 444-449, 2007.
Tauil PL. Aspectos críticos do controle do dengue no Brasil. Cad. Saúde Pública, Rio de Janeiro, 18(3): 867-871, 2002.

Tiew P, loset JR, Kokpol U, Chavasiri W \& Hostettmann K. Phytother. Res., 17: 190, 2003.

Vieira PC, Mafezoli J \& Biavatti MW. 2001. Inseticidas de origem vegetal. In: Ferreira JTB, Corrêa AG \& Vieira PC (orgs.). Produtos naturais no controle de insetos. São Carlos, Editora da Universidade Federal de São Carlos, Série de textos da Escola de Verão em Química, v. III. 234p.

Zoghbi MGB, Andrade EHA, Oliveira J \& Carreira MM. Yield and chemical composition of the essential oil the stems and rhizomas of Cyperus articulatus L. cultivated in the State of Pará, Brazil. J. Essent. Oil Res., 18: 10-12, 2006.

\section{Biodiversidade Brasileira - BioBrasil \\ Fluxo Contínuo}

n. 3,2020

http://www.icmbio.gov.br/revistaeletronica/index.php/BioBR

Biodiversidade Brasileira é uma publicação eletrônica científica do Instituto Chico Mendes de

Conservação da Biodiversidade (ICMBio) que tem como objetivo fomentar a discussão $e$ a disseminação de experiências em conservação e manejo, com foco em unidades de conservação $e$ espécies ameaçadas.

ISSN: 2236-2886 